\section{Playing under new rules}

\section{Dresden}

IF it had not been for German unification, Manfred von Ardenne, the renowned 84-year-old eastern German cancer researcher and polymath, might have been able to pursue his unorthodox theory of cancer treatment until his hundredth birthday, undisturbed by such Western trappings as peer review and open competition for research funds.

But, as in so many cases in the former East Germany, unification has changed everything. Now von Ardenne, a baron by birth who has been promoting his theories for more than 25 years with all the considerable (political) means at his disposal, is being asked to prove scientifically that his projects are worth supporting. $\mathrm{He}$ has no guarantee they will be approved. His change of fortune offers a revealing insight into the way research decisions were often made in East Germany and other Soviet bloc countries and of how things have changed.

In Germany, von Ardenne's name is a household word virtually synonymous with 'inventive genius'. He left school at 16 without graduating, and he filed for his first patent - on a vacuum tube - a month later. Later, he left Berlin University after four terms to work on radio and the precursors of television, and in 1931 he built and demonstrated a crude early television set called a 'flying spot scanner'. He is generally credited with conceiving the scanning electron microscope in 1937, although the first working models were not constructed until much later, and not by him.

After the Second World War, he worked for the Soviets on isotope separation for the atomic bomb. For that, he received the Stalin Prize, worth several hundred thousand rubles.

Von Ardenne took advantage of the cash and his status as a Soviet hero to set himself up as a scientific power in East Germany. Buying several elegant villas in a smart area of Dresden, he established a private research institute - the only one in East Germany. There he initiated studies into electron-beam technology and vacuum tubes, work that gradually grew into a self-supporting business.

In 1964, bolstered by his successes in fields where he had no theoretical background or experience, von Ardenne launched into what would become his consuming passion: cancer research. $\mathrm{He}$ established a new section of his institute devoted to the development of cancer therapy based on the unorthodox theories of Otto Warburg, a 1931 Nobel laureate who had triggered von Ardenne's interest in the field.

The resulting three-step cancer therapy is controversial, to say the least. The in Dresden. theories.) patient is first infused with a glucose solution to raise blood glucose to six times normal - a process that von Ardenne says acidifies tumour tissue and sensitizes it to heating. Next, the patient breathes a high-oxygen air mixture. Finally, the patient is heated until the core body temperature reaches 41.5 to $42.5^{\circ} \mathrm{C}$. This, von Ardenne says, preferentially kills the tumour cells.

Mainstream cancer researchers in Germany criticize the treatment. Typical is Oliver Lange of the Robert Janker Clinic, a private cancer hospital in Bonn, who describes von Ardenne's theories as more in the realm of religious belief than

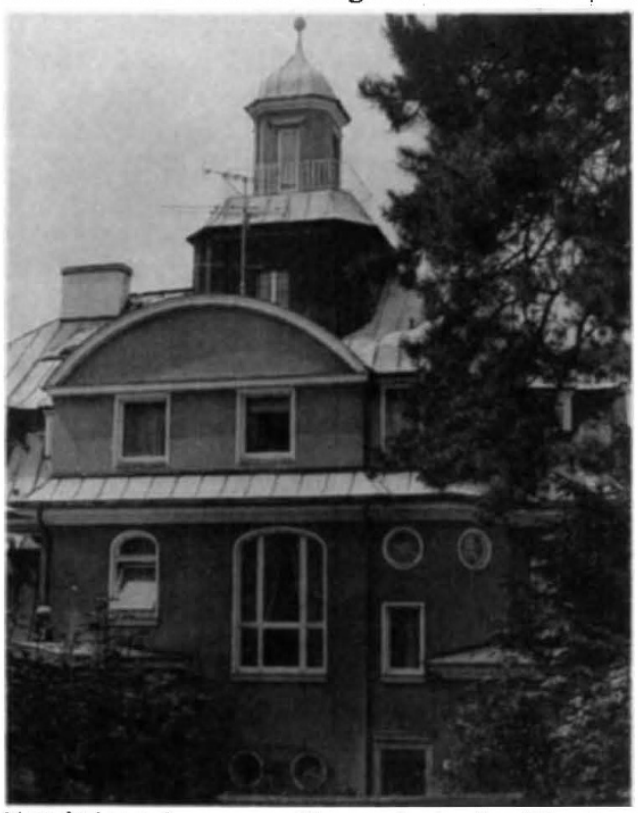

Von Ardenne's prewar villa overlooks the Elbe river provide some revenue, von Ardenne

science. (Lange stresses that this is his personal opinion and not that of the clinic, which is applying for money for a controlled test of some of von Ardenne's

Even within his own institute, von Ardenne is an embattled figure. "There always was a high turnover here," says Wolf-Karsten Mayer, a staff physician who came to the institute in 1986. "Highly qualified people especially usually left in a hurry," he adds, in part because von Ardenne insisted on publishing results before the experiments were complete or properly controlled.

Von Ardenne has an answer for all his critics. "They are uninformed," he says. "Or maybe they are jealous." He invites anyone to visit the institute and witness the success of the treatment for themselves. "I have over 400 publications," he says. "Maybe people have not had time to read them all." But that record does not carry quite the same weight as it would in the West. "Ninety per cent of [von Ardenne's] publications have ap- peared in his own private publishing house," says oncologist Rolf Issels of the University of Munich.

Even institute staff members admit that a large majority of von Ardenne's publications appeared in East German journals of doubtful quality - journals to which von Ardenne had easy access.

As long as von Ardenne was working in East Germany, the criticism mattered little to him. He had a 'golden telephone' giving him access to the highest echelons of the government, Issels says. This access - and two million marks a year government support - allowed him to pursue his theories as he saw fit.

But times have changed. The unified German government, which has become interested in alternative cancer treatments, made it clear to von Ardenne that he will have to meet some stringent scientific and ethical criteria before he receives any more government grants.

So far, his institute as a whole has fared relatively well compared to other industrial research outfits since the collapse of the Communist system. It has shrunk from 500 to 220 employees, and the section for producing vacuum-tube equipment still needs a buyer or sponsor. But the section dealing with electron-beam technologies has been taken over by the Munich-based Fraunhofer Gesellschaft for the Advancement of Applied Research, whose approval is seen as a major compliment to the institute.

But this does not help the cancer research section. Although a new clinic for multi-step cancer therapy will says if he does not get additional support soon, cancer research at the institute will be in serious trouble.

So, with the help of Western researchers and his own team of clinicians, von Ardenne is seeking the scientific proof he needs to qualify for government support. Wolfgang Scheef of the Janker Clinic in Bonn has applied for government money to test part of von Ardenne's treatment under strictly controlled conditions. And a team of physicians at the von Ardenne institute is in the midst of its own trial to determine the effectiveness of the treatment.

Researchers in both parts of Germany are following the saga closely. Although most expect the treatment to be at best a limited success when it is finally tested in a controlled way, they do not hide their respect for von Ardenne's ability to prosper under a variety of systems.

And if the treatment unexpectedly stands up to Western scrutiny, it will provide a final triumph to cap a long scientific career.

Steven Dickman 